\title{
ОСОБЛИВОСТІ ТОРГОВОГО БАЛАНСУ НІМЕЧЧИНИ В УМОВАХ КРИЗОВОГО І ПОСТКРИЗОВОГО РОЗВИТКУ СВІТОВОЇ ЕКОНОМІКИ
}

\section{DOI: 10.32620/cher.2019.1.02}

Постановка проблеми. Враховуючи тенденції щодо глобалізації фінансових ринків та економічних відносин в цілому, а також причини та наслідки світової фінансової кризи, дослідження рівноваги платіжних балансів стають все більш актуальними. Метою статті є обгрунтування теоретичних засад формування платіжного балансу; вивчення концепцій та моделей регулювання платіжного балансу держави; визначення структурних елементів і з'ясування макроекономічного значення платіжного балансу; обгрунтування напрямків врівноваження балансу міжнародних розрахунків; дослідження впливу макроекономічної політики на стан платіжного балансу країни; формування стратегії зменшення дефіциту платіжного балансу. Об'єктом дослідження виступають моделі регулювання платіжного балансу держави. Методологічною основою дослідження стали способи і принципи обгрунтування наукового пізнання загальних та спеціальних методів і прийомів, що використані під час регулювання та визначення структурних елементів платіжного балансу. Основною гіпотезою дослідження стало припущення, що для благополуччя Німеччини, аналізуючи структуру ВВП за галузями за останні десять років, в майбутньому необхідно зробити акцент на розвиток тих галузей в яких зайнятість трохи знизилася за аналізований період. Виклад основного матеріалу. У статті розглянуто зародження поняття «платіжний баланс» в його сучасному розумінні. Вивчено країни, які були змушені робити публікацію платіжного балансу через виникнення інфляційних процесів. Досліджено торговий баланс Німеччини в умовах кризового і посткризового розвитку світової економіки. Оригінальність та практичне значення дослідження. Слід зазначити, що у науковому світі триває дискусія щодо визначення основних чинників та характеру їхнього впливу на платіжний баланс країни, а також причин виникнення дефіцитів платіжних балансів. Висновки дослідження. У даній роботі запропоновано підходи до комплексної оцінки рівноваги платіжних балансів держав на основі порівняльного аналізу трьох груп показників. За результатами апробації даного підходу проведено оцінку рівноваги платіжних балансів найбільших світових економік.

\section{Ключові слова:}

платіжний баланс, баланс поточних операцій, баланс послуг, баланс руху капіталів і кредитів.

\section{THE TRADE BALANCE OF GERMANY IN THE SKILLED CRISIS AND POST-CRISIS DEVELOPMENT OF WORLD ECONOMY}

Formulation of the problem. Taking into account the tendencies of globalization of financial markets and economic relations as a whole, as well as the causes and consequences of the global financial crisis, the study of balance of payments balances become more and more relevant. The purpose of the research is to justify the theoretical basis of the formation of the balance of payments; studying the concepts and models of regulation of the balance of payments of the state; definition of structural elements and clarification of the macroeconomic value of the balance of payments; substantiation of directions of balancing the balance of international settlements; studying the impact of macroeconomic policy on the country's balance of payments; the formation of a strategy for reducing the deficit of the balance of payments. The object of re-

${ }^{1}$ Артьомова Аліна Вадимівна, канд. техн. наук, доцент кафедри «Економіка та маркетинг», Національний аерокосмічний університет ім. М.Є. Жуковського «Харківський авіаційний інститут», м. Харків, Україна.

Artyomova Alina, $\mathrm{PhD}$ in Technical, Associate Profesor of Economics and marketing Department National Aerospace University «Kharkiv Aviation Institute», Kharkov, Ukraine.

ORCID ID: 0000-0002-6761-2066

e-mail: a.aryomova@gmail.ru

${ }^{2}$ Малкіна Марія Сергіївна, студ. спец. «Економіка підприємства», Національний аерокосмічний університет ім. М.Є. Жуковського «Харківський авіаційний інститут», м. Харків, Україна.

Malkina Mariya, student of Economics Enterprise Specialty National Aerospace University «Kharkiv Aviation Institute», Kharkov, Ukraine.

ORCID ID: 0000-0002-3249-4690

e-mail: malkina98@mail.ua 
search is the model of regulation of the balance of payments of the state. The methodological basis of the study was the methods and principles of the scientific knowledge of general and special methods and techniques used in the regulation and definition of the structural elements of the balance of payments. The hypothesis of the research is the assumption that for Germany's prosperity, analyzing the structure of GDP by industries over the past ten years, in the future it is necessary to focus on the development of those industries in which employment slightly decreased over the analyzed period. The statement of basic materials. The article deals with the origin of the concept of "balance of payments" in its modern sense. We studied countries that were forced to publish the balance of payments due to the emergence of inflationary processes. The trade balance of Germany in the conditions of crisis and post-crisis development of the world economy is investigated. The originality and practical significance of the research. It should be noted that in the scientific world there is a discussion on determining the main factors and the nature of their impact on the balance of payments of the country, as well as the causes of deficits in the balance of payments. Conclusions of the research. In this paper, approaches to a comprehensive assessment of the equilibrium of the balance of payments of the states are proposed on the basis of comparative analysis of the three groups of indicators. According to the results of the approbation of this approach, the balance of payment balances of the world's largest economies was assessed.

Key words:

balance of payments, balance of current operations, balance of services, balance of capital and loans.

\section{ОСОБЕННОСТИ ТОРГОВОГО БАЛАНСА ГЕРМАНИИ В УСЛОВИЯХ КРИЗИСНОГО И ПОСТКРИЗИСНОГО РАЗВИТИЯ МИРОВОЙ ЭКОНОМИКИ}

Постановка проблемыл. Учитывая тенденции глобализации финансовых рынков и экономических отношений в целом, а также причины и последствия мирового финансового кризиса, исследования равновесия платежных балансов становятся все более актуальными. Целью статьи является обоснование теоретических основ формирования платежного баланса; изучение концепций и моделей регулирования платежного баланса страны; определение структурных элементов и выяснения макроэкономического значения платежного баланса; обоснование направлений уравновешивания баланса международных расчетов; исследования влияния макроэкономической политики на состояние платежного баланса страны; формирование стратегии уменьшения дефицита платежного баланса. Объектом исследования выступают модели регулирования платежного баланса государства. Методологической основой исследования стали способы и принципы обоснования научного познания общих и специальных методов и приемов, использованных во время регулирования и определения структурных элементов платежного баланса. Основной гипотезой исследования стало предположение, что для благополучия Германии, анализируя структуру ВВП по отраслям за последние десять лет, в будущем необходимо сделать акцент на развитие тех отраслей, в которых занятость несколько снизилась за анализируемый период. Изложение основного материала. В статье рассмотрены зарождения понятия «платежный баланс» в его современном понимании. Изучено страны, которые были вынуждены делать публикацию платежного баланса из-за возникновения инфляционных процессов. Исследован торговый баланс Германии в условиях кризисного и посткризисного развития мировой экономики. Оригинальность и практическое значение исследования. Следует отметить, что в научном мире продолжается дискуссия относительно определения основных факторов и характера их воздействия на платежный баланс страны, а также причин возникновения дефицитов платежных балансов. Выводы исследования. В данной работе предложены подходы к комплексной оценке равновесия платежных балансов государств на основе сравнительного анализа трех групп показателей. По результатам апробации данного подхода проведена оценка равновесия платежных балансов крупнейших мировых экономик.

Ключевые слова:

платежный баланс, баланс по текущим операциям, баланс услуг, баланс движения капиталов и кредитов.

Постановка проблеми. В умовах кризового і посткризового розвитку світової економіки кожна держава прагне мати достовірну і об'єктивну інформацію про результат зовнішньоекономічних операцій країни з рештою світу. Така інформація необхідна для прийняття рішень щодо майбутніх фінансо- вих дій на товарних і грошових ринках. Основні потреби в подібній інформації задовольняють баланси міжнародних розрахунків.

Останнім часом, враховуючи тенденції щодо глобалізації фінансових ринків та економічних відносин в цілому, а також причини та наслідки світової фінансової кризи, дослі- 
дження рівноваги платіжних балансів стають все більш актуальними.

Аналіз останніх досліджень і публікацій. Значний науковий внесок у розробку теоретичних положень, методичних і практичних питань складання платіжного балансу зробили вітчизняні та зарубіжні вчені, зокрема, Д. Срін, М.Т. Губером [4], В. Цоллінгера [5]; У. Фелнер [6], О. Анісімова, С. Боринець, П. Кругман, А. Мельник, Р. Моторин, С. Ніколайчук, М. Пебро, Т. Савченко, О. Сунцова, А. Шкляр, В. Юрчишин, Козак Л.С., та інші. Слід зазначити, що у науковому світі триває дискусія щодо визначення основних чинників та характеру їхнього впливу на платіжний баланс країни, а також причин виникнення дефіцитів платіжних балансів.
Мета статті $є$ обгрунтування теоретичних засад формування платіжного балансу; вивчення концепцій та моделей регулювання платіжного балансу держави; визначення структурних елементів і з'ясування макроекономічного значення платіжного балансу; обгрунтування напрямків врівноваження балансу міжнародних розрахунків; дослідження впливу макроекономічної політики на стан платіжного балансу країни; формування стратегії зменшення дефіциту платіжного балансу.

Виклад основного матеріалу дослідження. Платіжний баланс - це співвідношення фактичних платежів, здійснених даною країною за кордоном. Розвиток поняття «платіжний баланс» надано у табл. 1.

Т а бли и я 1

Розвиток поняття «платіжний баланс»

\begin{tabular}{|c|c|}
\hline $\begin{array}{c}\text { Ким, де і коли було запропоновано поняття } \\
\text { «платіжний баланс» }\end{array}$ & Трактування поняття «Платіжний баланс» \\
\hline $\begin{array}{l}\text { Е. Місселден в трактаті «Коло торгівлі» }(1623 p) \text {. } \\
\text { Робляться перші розрахунки торгового балансу } \\
\text { для Англії за } 1621 \mathrm{p}[1] .\end{array}$ & $\begin{array}{l}\text { Зародженням поняття «платіжний баланс» в йо- } \\
\text { го сучасному розумінні можна вважати появу } \\
\text { терміна «торговий баланс». }\end{array}$ \\
\hline $\begin{array}{l}\text { Т. Манна. У книзі «Багатство Англії у зовніш- } \\
\text { ній торгівлі» (1664p.) [2]. }\end{array}$ & $\begin{array}{l}\text { Пропонує поняття «загальний торговельний ба- } \\
\text { ланс», що характеризує відношення Англії з усі- } \\
\text { ма країнами в сукупності. }\end{array}$ \\
\hline $\begin{array}{l}\text { Д. Стюардом в роботі «Дослідження про прин- } \\
\text { ципи політичної економіки» (1767p.) }\end{array}$ & $\begin{array}{l}\text { Розглянув взаємозв'язок між торгівлею і рухом } \\
\text { капіталу [3]. }\end{array}$ \\
\hline \multicolumn{2}{|c|}{$\begin{array}{l}\text { Таким чином, протягом більше } 150 \text { років термін «платіжний баланс» був пов'язаний тільки } 3 \text { між- } \\
\text { народним рухом фінансових активів і відокремлювався від торгового балансу. Торговий баланс } \\
\text { формується як різниця між імпортом і експортом товарів (без урахування послуг). }\end{array}$} \\
\hline $\begin{array}{l}\text { Державними органами термін «платіжний ба- } \\
\text { ланс» вперше був використаний в } 1819 \text { р в Анг- } \\
\text { лії в доповіді парламентської комісії, що дослі- } \\
\text { джує стан міжнародних розрахунків країни. }\end{array}$ & $\begin{array}{l}\text { статистика того часу не могла надати необхідну } \\
\text { інформацію для складання необхідного балансу, } \\
\text { і проводилися лише експертні роботи різними } \\
\text { авторами. }\end{array}$ \\
\hline $\begin{array}{l}\text { Мак Кай, Р.Гіфф, Ч. Гобсон до початку першої } \\
\text { світової війни }\end{array}$ & $\begin{array}{l}\text { Проблема відсутності одностайного міжнарод- } \\
\text { ного терміна зростала. }\end{array}$ \\
\hline $\begin{array}{l}\text { Сесія Міжнародного інституту статистики в } \\
\text { Лондоні }(1905 \text { р) }\end{array}$ & $\begin{array}{l}\text { Надана допрацьована схема платіжного балансу. } \\
\text { Виникло питання про розробки більш гнучкої } \\
\text { системи валютних курсів. }\end{array}$ \\
\hline Англія в1919 році. & Почала публікацію платіжного балансу. \\
\hline $\begin{array}{l}\text { Ліга Націй з } 1924 \text { року публікує платіжні балан- } \\
\text { си різних країн. }\end{array}$ & Публікує платіжні баланси різних країн [7]. \\
\hline $\begin{array}{l}\text { Після світового фінансово-економічної кризи } \\
2008 \text { р. }\end{array}$ & $\begin{array}{l}\text { Нові тенденції розвитку глобального фінансово- } \\
\text { го ринку, зумовили необхідність перегляду ме- } \\
\text { тодів обліку зовнішньо-економічних операцій в } \\
\text { рамках структури рахунків платіжного балансу. }\end{array}$ \\
\hline
\end{tabular}

Джерело: узагальнено авторами на підставі $[1,2,3,7]$

Таким чином, спочатку платіжний баланс відображав тільки скоєні платежі, а не всі зовнішньоекономічні операції 3 матеріальними, фінансовими та інтелектуальними активами. Найбільш інформативний баланс, що відображає всі потоки активів, як приватні, так і офіційні, пов'язані з рухом товарів i послуг (рис. 1.). 


\section{ПЛАТІЖНИЙ БАЛАНС}

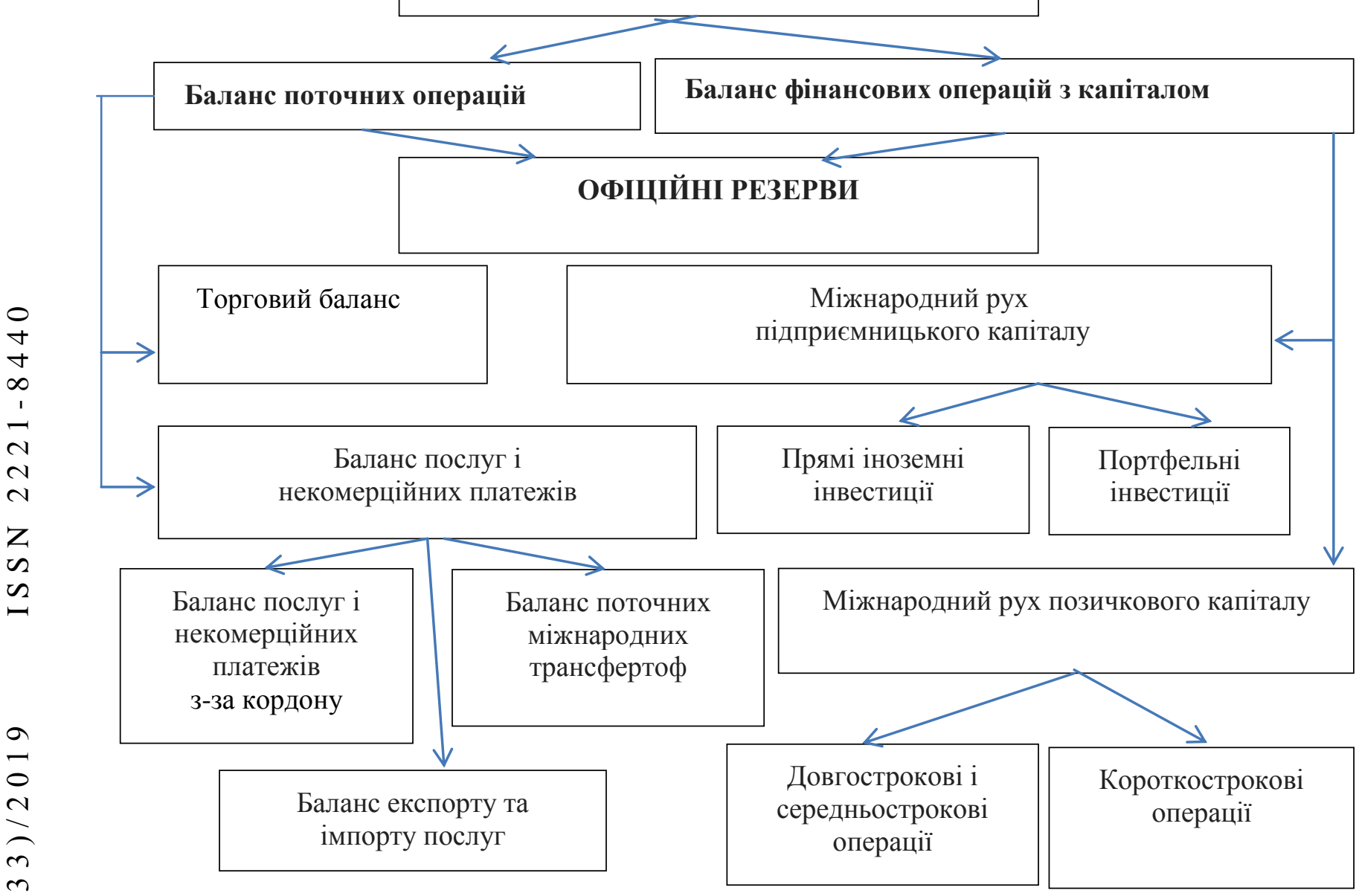

Рис. 1. Структура платіжного балансу

Джерело: розроблено авторами

Серед лідерів світової економіки знаходяться країни Північної Америки (США і Канада), Західної Свропи (перш за все Великобританія, Німеччина, Італія і Франція), Східної Азії на чолі з Японією. До передових економік світу відносять також чотирьох східно «тигрів» (Південна Корея, Сінгапур, Гонконг, як особливий адміністративний район Китаю, і Тайвань), Ізраїль і Кіпр.

Сучасна Німеччина належить до однієї 3 найбільш розвинених країн світу. За оцінками, частка Німеччини в світовому ВВП в 2017 р склала, що відповідає 4-му місцю в світі слідом за Китаєм, який швидко розвивається.

ВВП на душу населення Німеччини в постійних цінах, розрахований за паритетом купівельної спроможності, склав в 2015 році 43 тис. дол. Середньорічний темп приросту за аналізований період дорівнював 1,3\%. Більш високий темп приросту ВВП на душу населення в порівнянні із загальним ВВП пов'язаний 3 тим, що в Німеччині за останні десять років чисельність населення зменшилася на $0,9 \%$ - $з$ 82,3 млн. в 2007 році до 81,6 млн. в 2017 році. 


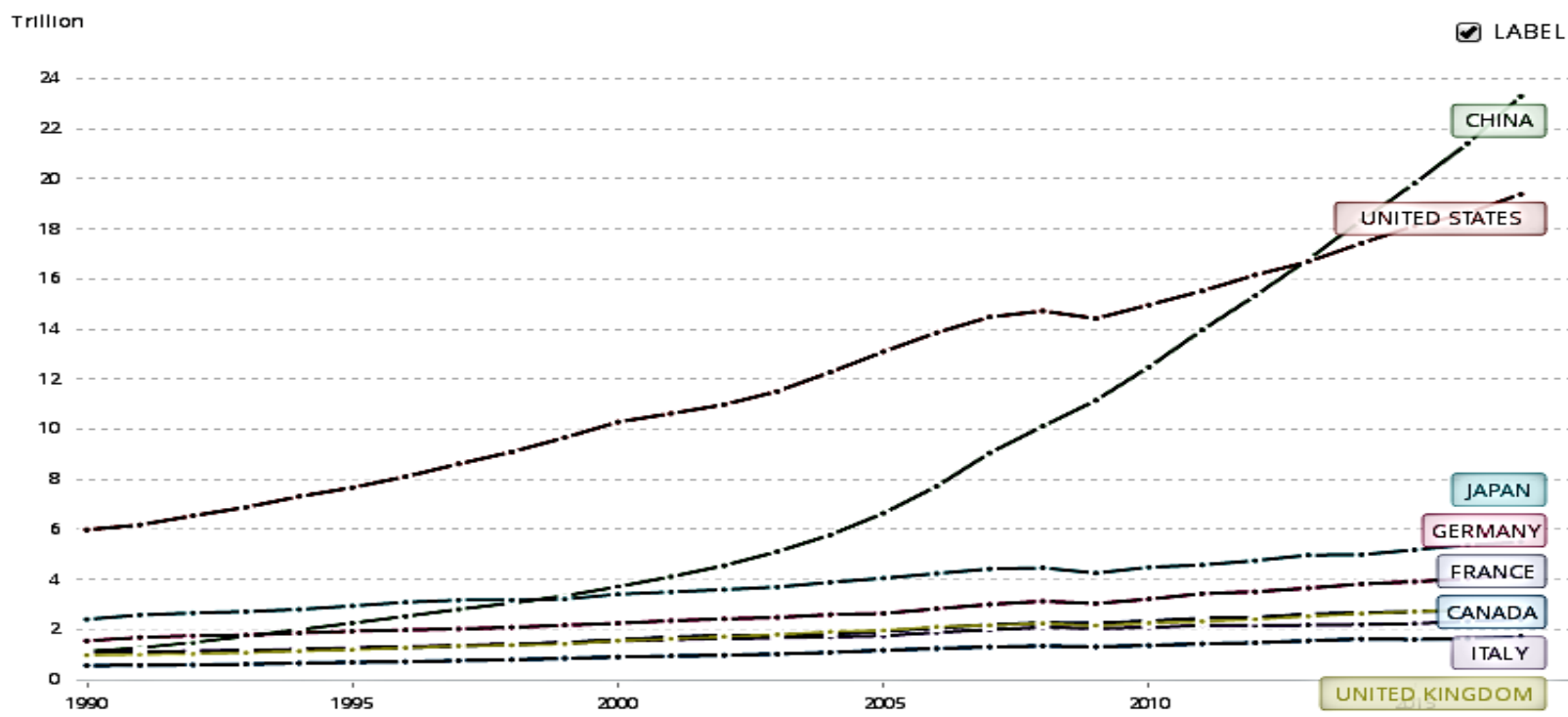

Рис. 2. ВВП країн лідерів світової економіки

Джерело: структуровано авторами на основі офіційної статистики $[8,9]$

Аналізуючи структуру ВВП Німеччини за галузями в постійних і поточних цінах, чітко видно, що за останні десять років додана вартість змінювалися по різному. Реальний приріст, більш ніж на $30 \%$, спостерігався тільки в логістиці та телекомунікаційних послугах. Отже, уряд Німеччини вирішив, що для благополуччя всієї країни в майбутньому необхідно зробити акцент на розвиток цих галузей. Також варто відзначити, що зайнятість в цих галузях трохи знизилася за аналізований період. Це означає, що різке збільшення доданої вартості в логістиці та теле- комунікаційних послугах було досягнуто за рахунок зростання продуктивності праці.

Структура торгового балансу Німеччини. Розглядаючи структуру торгового балансу Німеччини за останні десять років можна відзначити, що постійно формується негативне сальдо торгового балансу сільськогосподарських і сировинних товарів (рис. 3). Отже, Німеччина вважає за краще купувати певні товари сільського господарства за кордоном, так як їй через природно-кліматичних умов недоцільно вирощувати їх на своїй території.

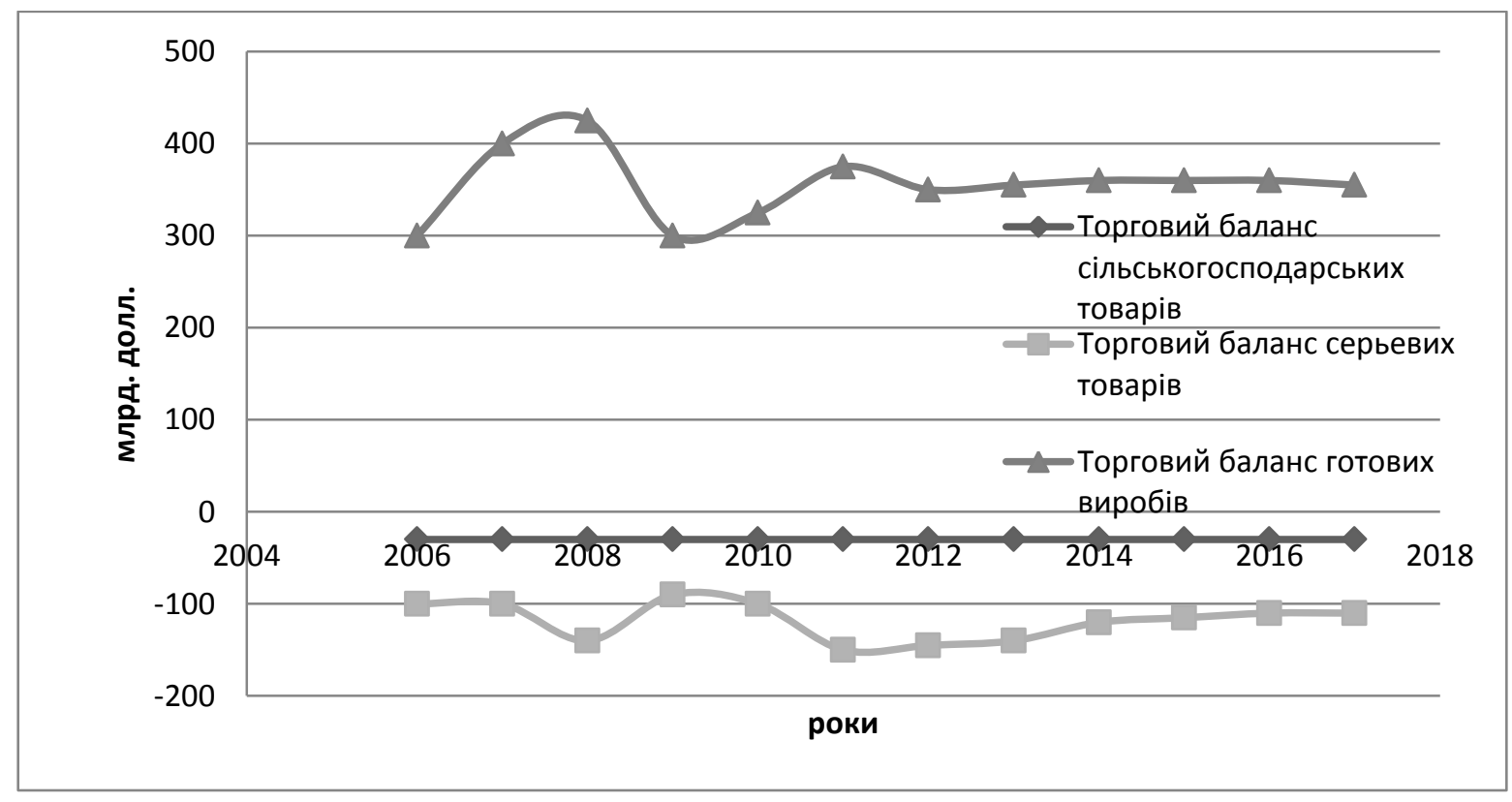

Рис. 3. Структура торгового балансу Німеччини (2006-2017гг.)

Джерело: структуровано авторами на основі офіційної статистики $[8,9]$ 
Аналогічна ситуація спостерігається 3 сировинними товарами. Через брак власних природних ресурсів Німеччина змушена щорічно докуповувати їх на зовнішньому ринку на \$ 100- \$ 150 млрд. Значні коливання величини торгового балансу викликані коливаннями світових цін на сиру нафту і природний газ, так як їх частка в загальній виручці імпорту сировини становить понад $90 \%$.

Дефіцит торгового балансу сільськогосподарських і сировинних товарів фінансу- ється за рахунок величезного профіциту торгового балансу готових виробів. Тобто Німеччина не тільки обмінюється готовими виробами з іншими розвиненими країнами, але ще і виробляє ці товари для них на своїй теритоpiï. В результаті протягом багатьох років в Німеччині постійно формується величезний профіцит торгового балансу товарів, який значно перевищує дефіцит торгового балансу послуг (рис. 4).

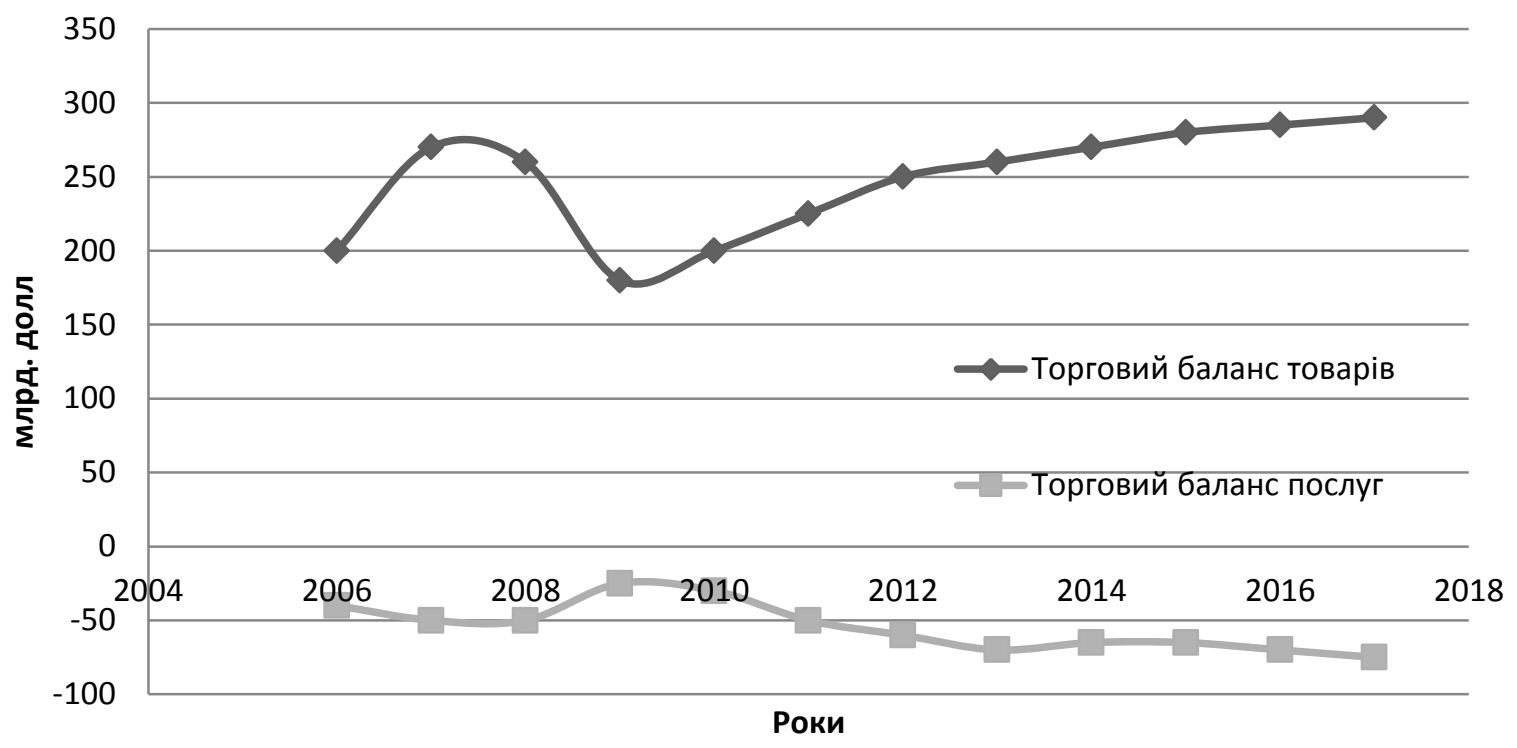

Рис. 4. Торговий баланс товарів і послуг Німеччини (2006-2017гг.) Джерело: структуровано авторами на основі офіційної статистики $[8,9]$

32016 Німеччина мала позитивне сальдо торгового балансу в розмірі $\$ 280$ мільярди чистого експорту. Високий позитивний баланс означає, що продукція даної країни популярна на світових ринках, при цьому популярність імпорту у споживачів низька. Згідно $з$ даними, загальний обсяг експорту товарів зріс на $1,2 \%$ до $€ 1,2$ трильйона в порівнянні з 2015 роком. Обсяги торгівлі з країнами СС збільшилися на 2,2\%, а 3 іншими країнами світу - на 0,2\%. У 2016 році відбулося збільшення експорту товарів на $2,5 \%$ до $€$ 1,23 трильйона. Що стосується імпорту товарів, то його загальний обсяг зріс в 2016 році на $0,6 \%$ до € 954,6 млрд.

\section{Висновки та перспективи подальших} досліджень. Таким чином, сутність платіжного балансу як системи опису всіх економічних угод за певний період між резидентами країни полягає в тому, що він дозволяє зробити вірні висновки щодо зовнішньоекономічних позицій країни. У даній роботі запропо- новано підходи до комплексної оцінки рівноваги платіжних балансів держав на основі порівняльного аналізу трьох груп показників. За результатами апробації даного підходу проведено оцінку рівноваги платіжних балансів найбільших світових економік.

\section{Література}

1. История экономических учений / Под ред. В. Автономова, О. Ананьина,. Н. Макашевой: Учеб. пособие.М.: ИНФРА-М, 2008. - 710 c.

2. Thomas M. England's Theasure by Foreing Trade or The Balance of our Foreing Trade is The Rule of our Theasure. London: J.C. for Thomas Clark, 1964.

3. Stuart James. An Inquiry into the Principles of Political Economy. London: New Series. - 1961. Vol. 28 - №. 109 - P. 53-61. 
4. Губер М. Т. Как читать баланс / М. Т. Губер // Международные отношения. - 1995. - № 3. - C. 14-18.

5. Цоллингер B. Международное перемещение ценностей и помещение капитала за границей, их влияние на производство и конъектуру / В. Цоллингер // Журнал общественно-политических наук. -1869.

6. Fellner $W$. Monetary policies and full employment. / W. Fellner. Hamden: Competition among the few, N.Y., 1949. -268 p.

7. League Of Nations. Memorandum on balance of payments and foreign trade balance Vol. 1. - Geneva, 1926.

8. Статистичний збірник «Зовнішня торгівля України товарами та послугами у 2017 році». [Електронний ресурс]. - Режим доступу:

http://ukrstat.gov.ua/druk/publicat/kat_u/2018/zb /06/zb_ztutp2017.pdf

9. Німеччина Огляд ринку. [Електронний ресурс]. - Режим доступу: http://www.compet.kh.gov

\section{References}

1. Avtonomova, V. \& Ananyina, O. \& Mukasheva, N. (2008). History of Economic Teaching. Moscow: INFRA-M, 710.

Стаття надійшла

до редакції : 08.01.2019 p.
2. Thomas, M. (1964). England's Theasure by Foreing Trade or The Balance of Foreing Trade is The Rule of our Theasure. London: J.C. for Thomas Clark.

3. Stuart James. (1961). An Inquiry into the Principles of Political Economy. London: New Series, 28, 109, 53-61.

4. Guber, M. T. (1995). How to read the balance. International relations, 3, 14-18.

5. Zollinger, $V$. (1869). International transfer of values and placement of capital abroad, their influence on production and the conect. Journal of General and Political Sciences.

6. Fellner, W. (1949). Monetary policies and full employment. Hamden: Competition among the few, N.Y., 268.

7. League of Nations. (1926). Memorandum on balance of payments and foreign trade balance, Vol. 1. Geneva.

8. Statistical collection "Ukraine's foreign trade in goods and services in 2017". Retrieved from:

http://ukrstat.gov.ua/druk/publicat/kat_u/2018/zb /06/zb_ztutp2017.pdf

9. Germany Market Overview. Retrieved from: http://www.compet.kh.gov

Стаття прийнята

до друку: 29.03.2019 р.

Бібліографічний опис для цитування :

Артьомова А. В. Особливості торгового балансу Німеччини в умовах кризового і посткризового розвитку світової економіки / А. В. Артьомова, М. С. Малкіна // Часопис економічних реформ. - 2019. - № 1 (33). - С. 13-19. 